\title{
Two-phase anaerobic co-digestion of used vegetable oils' wastes and pig manure
}

\author{
D. Hidalgo • M. Gómez · J. M. Martín-Marroquín • \\ A. Aguado $\cdot$ E. Sastre
}

Received: 17 June 2013/Revised: 10 February 2014/ Accepted: 17 March 2014/Published online: 9 April 2014

(C) Islamic Azad University (IAU) 2014

\begin{abstract}
The purpose of this work was to study the anaerobic co-digestion of all the by-products generated during the processing of used vegetable oils (UVO) with the objective of proposing a solution for the treatment of these wastes. More specifically, this study investigates the advantages of two-phase anaerobic digestion for treating a mixture $(1 / 5 \mathrm{v} / \mathrm{v})$ of UVO processing wastes $(\mathrm{OW})$ and pig manure (PM) using two semi-continuous digesters operated at mesophilic temperature $\left(37 \pm 1{ }^{\circ} \mathrm{C}\right)$. The experiments were conducted at hydraulic retention time (HRT) of $0.5,1$, 2 and 4 days in the first stage (acidifier) and at HRT of 11.5, 15,18 and 20 days in the second stage (methaniser). The results revealed that the HRT had a high influence on the soluble chemical oxygen demand (sCOD) and total dissolved solids (TDS) removal. The maximum total sCOD removal efficiency of $86.4 \%$ and TDS removal efficiency of $81.9 \%$ was achieved at 20 days of global HRT. The maximum biogas production of $0.65 \mathrm{~m}^{3}$ per kilogramme of volatile dissolved solids (VDS) was removed, corresponding to a methane production of $0.42 \mathrm{~m}^{3} \mathrm{CH}_{4} \mathrm{~kg}^{-1}$. VDS removed $\left(65 \% \mathrm{CH}_{4}\right)$ was also achieved at 20 days of HRT. The two-phase digestion system showed good stability, which was mainly attributed to the strong buffering capacity with the two-phase system and the high alkalinity from PM when co-digested with OW. The results obtained from this study provide fundamental information for scaling up a high-performance two-phase anaerobic system in the future.
\end{abstract}

D. Hidalgo $(\varangle)$ · M. Gómez · J. M. Martín-Marroquín .

A. Aguado · E. Sastre

CARTIF Centro Tecnológico, P.T. Boecillo, Valladolid, Spain

e-mail: dolhid@cartif.es

D. Hidalgo · J. M. Martín-Marroquín · A. Aguado

ITAP Institute, University of Valladolid, Valladolid, Spain
Keywords Co-digestion - Hydraulic retention time - Oily waste $\cdot$ Pig manure $\cdot$ Two-phase anaerobic reactor $\cdot$ Used vegetable oil

\section{Introduction}

Energy from waste is regarded as one of the most dominant future renewable energy sources, since it can provide a continuous power generation (Appels et al. 2011).

Used vegetable oils (UVO) are a promising alternative to the use of edible oils as feedstock for biodiesel production. The European Union produces 700,000 to 1 million tons a year of UVO, and most of them are disposed improperly (Chhetri et al. 2008; Kulkarni and Dalai 2006).

UVO can produce blockades in pipes and make sewage treatment more difficult when disposed through the sink. The EU strongly favours and supports the recovery of UVO for biofuels production as it fits in the strategy of reducing dependency on petrol fuels (EU 2006), minimising greenhouse gas emissions, decreasing engine pollution, and at the same time, it is a way to reduce waste disposal that can contaminate soils and waters.

When UVO is collected, it goes to a pre-treatment process to eliminate moisture and bulky particulate and then through a refining process to eliminate free fatty acids and other undesirable compounds before sending it for biodiesel production. Nowadays, the increasing amount of wastes generated in this sector as consequence of the pretreatment and refining processes means an environmental problem. Inadequate management and uncontrolled disposal have influenced both water bodies and nearby communities and have raised health concerns (Refaat 2010).

Anaerobic digestion (AD) of residues from the pretreatment process and by-products of the refining process 
have the potential to achieve an efficient pollution reduction as well as the advantage of conserving energy and providing opportunities for environmental and socioeconomic benefits (Appels et al. 2011; Torrijos et al. 2008). On the other hand, it is well known that oil-rich wastes $\mathrm{AD}$ is not always easy and simple, since anaerobes are very sensitive to lipid-rich matters, to surfactants producing during oil hydrolysis as well as to intermediate compounds of oily wastes degradation process (Hidalgo et al. 2013; Hong 2011; Neves et al. 2009; Zhang et al. 2010).

Lipids cause operational problems in anaerobic digesters due to clogging and may also cause mass transfer problems for soluble substrates, since they become adsorbed to the microbial biomass surface. The flotation of biomass due to adhesion of fat may also produce loss of active biomass because of washout (Cirne et al. 2007).

Nevertheless, lipids are attractive substrates for $\mathrm{AD}$, and co-digestion due to the higher methane yield obtained when compared with proteins or carbohydrates. In this context, lipid-rich waste can be regarded as a large potential renewable energy source (Mobarak-Qamsari et al. 2012). Ahrin (2003) described a significant increase $(100 \%)$ in the yield of methane when fish oil was added to a manure digester. The benefit of adding lipids to a digester in order to enhance methane production is therefore a promising approach, which should be better explored.

Two-phase AD systems plus co-digestion have been suggested for the treatment of waste streams containing high levels of lipids such as kitchen waste ( $\mathrm{Li}$ et al. 2010; Yang et al. 2013; Zhang et al. 2007), dairy waste (Demirer and Chen 2005; Ince 1998), ice cream factory effluents (Borja and Banks 1995), fish meal processing waste (Guerrero et al. 1999), slaughterhouse waste (Wang and Banks 2003) or olive mill solid waste (Beccari et al. 1998; Borja et al. 2002; Travieso et al. 2008). These studies have illustrated the potential advantages of two-phase AD over single-phase systems when treating complex substances, e.g. shorter retention time, higher gas conversion efficiency and higher methane concentration in the produced gas (Bouallagui et al. 2005; Demirer and Chen 2005; SenthilKumar et al. 2011; Yu et al. 2002). Furthermore, on one hand, it may allow a reduction in total reactor volume (Demirel and Yenigün 2002; Ince 1998), and on the other hand, co-digestion alleviates the inhibitory effect caused by high fat concentrations (Yang et al. 2013).

The two-phase AD system permits the selection and enrichment of different bacteria in each digester; in the first phase, complex pollutants are degraded by acidogenic bacteria into volatile fatty acids (VFA), which are subsequently converted to methane and carbon dioxide by acetogenic and methanogenic bacteria in the second phase. This configuration also increases the stability of the process by controlling the acidification phase in order to prevent overloading and the build-up of toxic material (Demirel and Yenigün 2002). Moreover, the first stage may act as a metabolic buffer, preventing $\mathrm{pH}$ shock to the methanogenic population; in addition, low $\mathrm{pH}$, a high organic loading rate and a short hydraulic retention time (HRT) are all factors that favour the establishment of the acidogenic phase and preclude the establishment of methanogens. With waste containing high concentrations of lipids, the first phase serves mainly to remove solids and, hence, achieves a more stable high-rate anaerobic reactor operation (Palenzuela 1999).

Acidogenic and methanogenic microorganisms differ not only in terms of their nutritional and $\mathrm{pH}$ requirements, but also with respect to their physiology, growth and nutrient uptake kinetics, and in their particular ability to withstand environmental changes. Consequently, conditions that are favourable to the growth of acid-forming bacteria (short HRT, low $\mathrm{pH}$ ) may be inhibitory to methane-forming bacteria. An advantage of two-phase digesters is that their operating conditions may be selectively determined in order to maximise not only acid but also methane-forming bacterial growth. Nonetheless, in the case of waste with a high content of biorecalcitrant substances, a certain level of methanogenic activity is permitted in the acidogenic reactor, since these bacteria consume $\mathrm{H}_{2}$, produced in the acidogenic phase (Solera et al. 2002).

Furthermore, two-phase AD has given the best performance in methane productivity and COD removal efficiency compared with one-phase conventional digestion (Göblös et al. 2008; Wust 2003).

Therefore, taking into account the potential advantages of two-phase $\mathrm{AD}$ and continuing the research of upgrading the anaerobic co-digestion of different wastes, the aim of the present work has been to assess the performance of two-phase anaerobic co-digestion of residues and subproducts from the used vegetable oil processing industry (OW) with pig manure (PM) in semi-continuous sequencing digesters operated at mesophilic temperature.

This report discusses a pilot scale research with the emphasis placed on the evaluation of biogas production optimal values and organic matter removal efficiencies of effluents under different HRTs. The research described in this paper was performed in laboratories of Centro Tecnológico CARTIF, Spain, in 2012-2013.

\section{Materials and methods}

Waste streams

The treatment of UVO is intended to yield a product with a given quality that satisfies the needs of the biodiesel industries. The treatment process of UVO involves several 
chemical and physical steps which generate a mixture of residues $(\mathrm{OW})$. In this study, OW were supplied by a biodiesel company located in Madrid (Spain).

$\mathrm{PM}$ proceeded from a swine-raising farm located nearby the city of Valladolid (Spain).

\section{Wastes analysis}

Total and volatile solid concentration (TS, VS), total and volatile dissolved solid concentration (TDS, VDS), chemical oxygen demand (COD), soluble chemical oxygen demand (sCOD), fat content, alkalinity, $\mathrm{P}$ and $\mathrm{pH}$ were determined following standard methods (APHA 2005) recommendations.

Fatty acids (FA) concentrations were determined using a gas chromatograph (HP-Agilent) equipped with a flame ionisation detector (FID). C, N, H and S contents were determined by UNE-CEN/TS 15104 EX with a LECO Truspec $\mathrm{CHN}(\mathrm{S})$ elemental analyser.

Oxygen content was not measured directly but was estimated assuming that no other elements (apart from the measured $\mathrm{C}, \mathrm{H}, \mathrm{N}, \mathrm{S}$ and $\mathrm{P}$ ) were present in the wastes.

\section{Biomethane potential (BMP) test}

In order to study the biodegradability and biomethane potential of different OW/PM mixtures, batch experiments were run in glass serum bottles with a liquid volume of $600 \mathrm{~mL}(2,000 \mathrm{~mL}$ of total volume).

All the experiments were carried out at $37 \pm 1{ }^{\circ} \mathrm{C}$ in a thermostatic room, and continuously stirred on a shakingtable. Anaerobic sludge from a municipal wastewater treatment plant, previously adapted to OW and PM mixtures, with a concentration of $12 \pm 1 \mathrm{gVS} \mathrm{L}^{-1}$, was used as inoculum for the anaerobic test.

The concentration of the inoculum in all the assays was $6.5 \mathrm{~g} \mathrm{~L}^{-1}$, and $\mathrm{pH}$ was 7.5. In this study, four OW/PM ratios were selected for the substrate, $1 / 0,1 / 1,1 / 3$ and $1 / 5$ $\mathrm{v} / \mathrm{v}$, and triplicate assays, for all the waste mixtures and conditions, were performed. Substrate/inoculum (S/X) ratios were in the range of $0.40-0.60 \mathrm{gVS}_{\text {waste }} \mathrm{gVS}_{\text {inoculum }}^{-1}$ for all the samples.

A set of triplicate blank assays without any waste (only inoculum) was also performed for endogenous methane production determination. To avoid acidification of the assay, $\mathrm{NaHCO}_{3}$ was added as buffer $\left(6 \mathrm{gNaHCO}_{3} \mathrm{~L}^{-1}\right)$. Experiments were finished when the biogas production rate in waste assays decreased to the same level as in the blank assays.

Biogas production was measured manually by a pressure transmitter (Druck, PTX 1400, range 1 bar) in the head space of each reactor. To avoid reaching overpressure, biogas in the head space was released periodically. Pressure differences were converted to biogas volume, using the ideal gas Law and standard temperature and pressure conditions (STP, $P=1$ bar and $T=0{ }^{\circ} \mathrm{C}$ ).

Biogas composition was measured before each release with a Varian CP-4900 Micro-GC with a thermal conductivity detector. Net methane production was calculated by subtracting the amount of the methane produced by the blank assay from the methane production of each assay.

\section{Experimental set-up}

In order to study the operational and performance characteristics of the two-phased $\mathrm{AD}$ when treating a mixture of OW and PM, the pilot plant schematically illustrated in Fig. 1 was constructed.

The system is comprised of a waste grinder, a homogenisation tank $\left(0.5 \mathrm{~m}^{3}\right)$, a continuous stirred tank acidification reactor (AR) $450 \mathrm{~mm}$ inner diameter and $700 \mathrm{~mm}$ height, made up of stainless steel with a working volume of $0.1 \mathrm{~m}^{3}$, a continuous stirred tank methanogenic reactor (MR) $800 \mathrm{~mm}$ inner diameter and 1,200 $\mathrm{mm}$ height, made up of stainless steel with a working volume of $0.5 \mathrm{~m}^{3}$, and a digested effluent tank. The acidogenic and methanogenic reactors were fabricated with 1:5 volumetric ratios to maintain shorter HRT in the AR as comparable with longer HRT in the MR.

The mission of the acidogenic reactor is to acidify the raw substrate in an effort to improve the performance of the methanogenic reactor by increasing the SV removal efficiencies and methane yield. In addition, the acidogenic reactor may also reduce the effect of shock loadings to the methanogenic reactor, increasing the stability of the twophase system.

The source materials were pre-treated by the grinder, then pumped into the AR and then forced from the AR into the MR. A check valve connects the AR with the MR, which was also connected with the digested effluent tank by another check valve.

Two thermometers and two $\mathrm{pH}$-meters were installed, one in the acidification reactor and another in the methane fermentation reactor. A pressure gauge was installed on the biogas line to monitor head-gas pressure in both fermentation reactors. Biogas generated was measured using two wet gas flow meters. The exteriors of the acidification reactor and the methane fermentation reactor were coated with a $5 \mathrm{~cm}$ layer of polyurethane foam for heat insulation, and the temperature was maintained at $37 \pm 1{ }^{\circ} \mathrm{C}$ by an electric heating jacket. Several ports were installed on the walls of the fermentation system for withdrawing samples. 


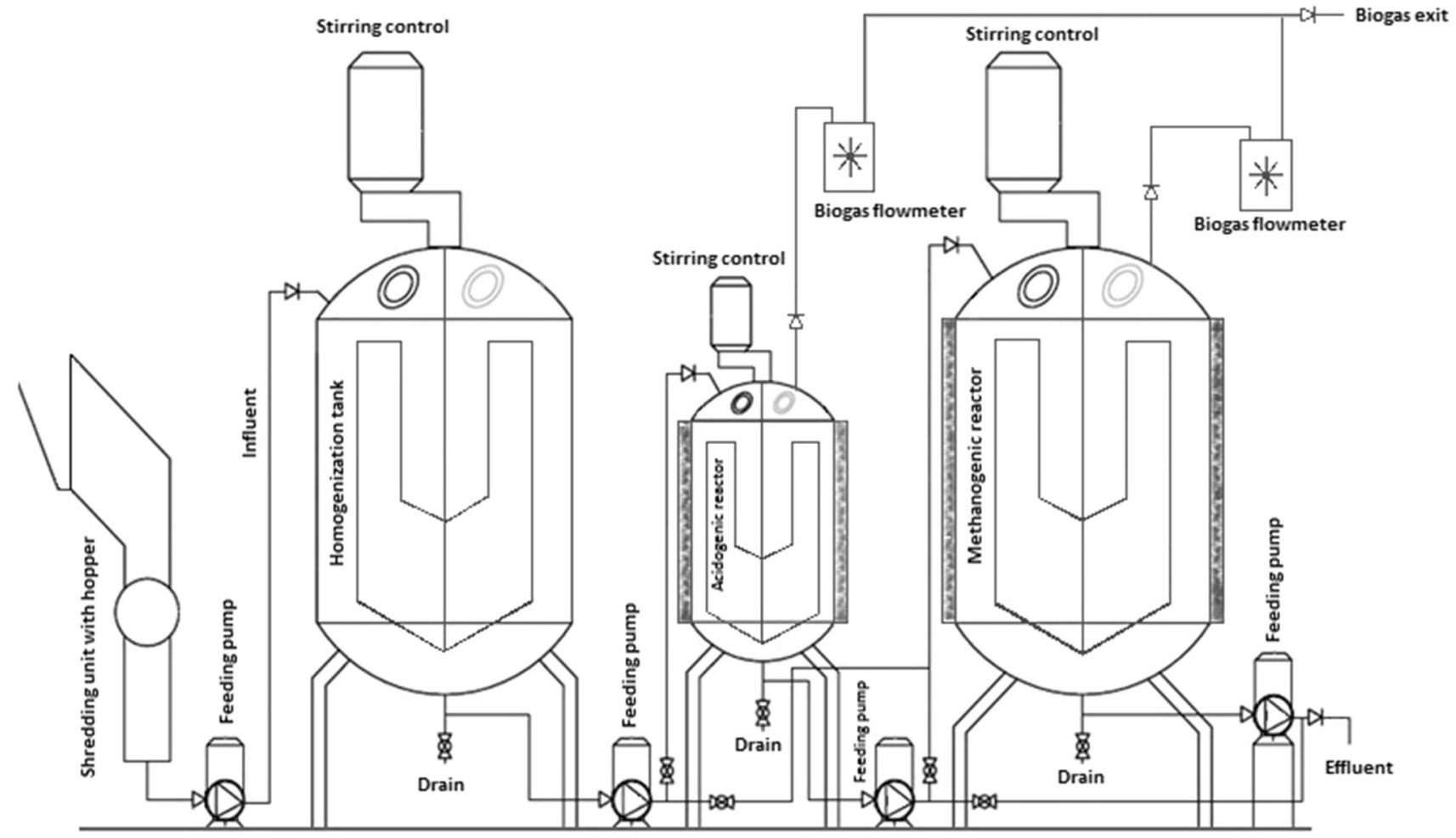

Fig. 1 Experimental set-up

\section{Results and discussion}

Waste composition

Lumped parameters as TS, VS, COD, total organic carbon (TOC) and total nitrogen (TN) are the most frequently analysed since they are the key when determining treatment optimisation. Furthermore, the analysis of the elemental composition provides information about the theoretical methane potential $\left(\mathrm{B}_{0, \mathrm{Th}}\right)$ of a given waste using Buswell's equation (1). This equation assumes methane production from the complete degradation of a certain waste with a given elemental composition, where $\mathrm{C}_{n} \mathrm{H}_{\mathrm{a}} \mathrm{O}_{\mathrm{b}} \mathrm{N}_{\mathrm{c}}$ represents the chemical formula of the biodegradable organic compound subjected to the anaerobic degradation process, and the production of methane considered herein is the maximum stoichiometrically possible (Lesteur et al. 2010). For a $\mathrm{C}_{n} \mathrm{H}_{\mathrm{a}} \mathrm{O}_{\mathrm{b}} \mathrm{N}_{\mathrm{c}}$ compound, the theoretical methane potential [at standard temperature and pressure conditions (STP)] is

$B_{0, \mathrm{Th}}=\frac{\left(\frac{n}{2}+\frac{a}{8}-\frac{b}{4}-\frac{3 c}{8}\right) \cdot 22.4}{12 n+a+16 b+14 c}|=| \frac{\mathrm{L} \mathrm{CH}_{4}}{\mathrm{~g} \mathrm{VS}}$

where the parameters $n, a, b, c$ refer to the stoichiometry index of $\mathrm{C}, \mathrm{H}, \mathrm{O}$ and $\mathrm{N}$, respectively.

Tables 1, 2 and 3 gather the results obtained from the characterisation of the selected raw wastes and their mixtures.

PM has a high content of ammonia in comparison with OW. Manure possesses a high alkalinity, while the

Table 1 Waste characterisation

\begin{tabular}{|c|c|c|c|c|c|c|c|c|}
\hline \multirow[t]{2}{*}{ Waste } & \multicolumn{7}{|c|}{ Physico-chemical parameters } & \multirow[t]{2}{*}{ Protein $(\%)$} \\
\hline & $\mathrm{pH}^{-}$ & Alkalinity $(\mathrm{mM})$ & $\mathrm{N}-\mathrm{NH}_{4}\left(\mathrm{gN} \mathrm{L}^{-1}\right)$ & $\mathrm{TS}\left(\mathrm{g} \mathrm{L}^{-1}\right)$ & $\mathrm{VS}\left(\mathrm{g} \mathrm{L}^{-1}\right)$ & $\mathrm{VS} / \mathrm{TS}^{-}$ & Fat content $(\%)$ & \\
\hline OW & 6.5 & 30 & - & 391.4 & 374.1 & 0.95 & 49.6 & 2.7 \\
\hline PM & 7.7 & 282 & 4.9 & 44.9 & 30.7 & 0.68 & - & - \\
\hline Mixture 1/1 & 7.0 & 160 & 2.5 & 225.5 & 212.4 & 0.94 & 24.8 & 1.4 \\
\hline Mixture $1 / 3$ & 7.1 & 202 & 3.7 & 141.5 & 116.6 & 0.82 & 12.4 & 0.7 \\
\hline Mixture $1 / 5$ & 7.2 & 240 & 4.1 & 115.6 & 99.0 & 0.86 & 8.3 & 0.4 \\
\hline
\end{tabular}


alkalinity of OW is low. On the other hand, OW have a high content of fats and proteins in contrast to manure. The characterisation of the wastes indicates that co-digestion with PM could be a cost-effective method to treat OW without the need to add nitrogen source or chemicals for increasing buffer capacity or adjusting $\mathrm{pH}$, in accordance with Zhang et al. (2011).

Palmitic, linoleic and oleic are the most abundant long chain fatty acids (LCFA) in the OW samples (Table 2). The concentrations of the other acids were always much lower. Lalman and Bagley (2001) reported that palmitic acid was the main product detected from oleic and linoleic acids anaerobic degradation, so their presence in the batch experiments and in the two-phase reactor is expected in this study.

These three compounds have been identified as inhibitors for methanogens. Even at low concentrations, these compounds can be adsorbed on the cell membrane

Table 2 Fatty acids in OW

\begin{tabular}{lr}
\hline FA & $(\%)$ \\
\hline Araquid acid & 0.45 \\
Behenic acid & 0.77 \\
Capric acid & 0.01 \\
Caprilic acid & 0.05 \\
Cerotic acid & 0.01 \\
Estearic acid & 5.92 \\
Heneicosanoic acid & 0.01 \\
Lauric acid & 0.05 \\
Lignoceric acid & 0.25 \\
Linoleic acid & 31.76 \\
Linolelaidic acid & 0.09 \\
Margaric acid & 0.11 \\
Miristic acid & 0.46 \\
Oleic acid & 45.65 \\
Palmitic acid & 13.84 \\
Palmitoleic acid & 0.55 \\
\hline
\end{tabular}

interfering with mass transfer across the membrane (Pastor et al. 2013).

Previous works (Beccari et al. 1998) on the anaerobic treatment of oily wastes have shown that the inhibition of methane production is mainly caused by the high presence of lipids, this is why the co-digestion of these wastes with non-oily wastes (as PM) is a key factor to prevent inhibition of methanogenesis since the lipids concentration is lowered.

\section{Specific methane potential}

Figure 2 shows the cumulative specific methane production of the wastes at the different mixture ratios assayed. All the biodegradability assays were conducted in triplicate, and the maximum deviation reported was $\pm 15 \mathrm{mLCH}_{4} \mathrm{gSV}^{-1}$ for every assay set.

The methane production pattern observed was similar to the ones reported by Cirne et al. (2007) for batch degradation of a lipid-rich waste. The initial lag phase in methane production observed for all tests could be attributed to the rapid build-up of FA, as proposed by Salminen et al. (2000). The maximum methane production rate observed was similar for tests with mixture of OW and PM

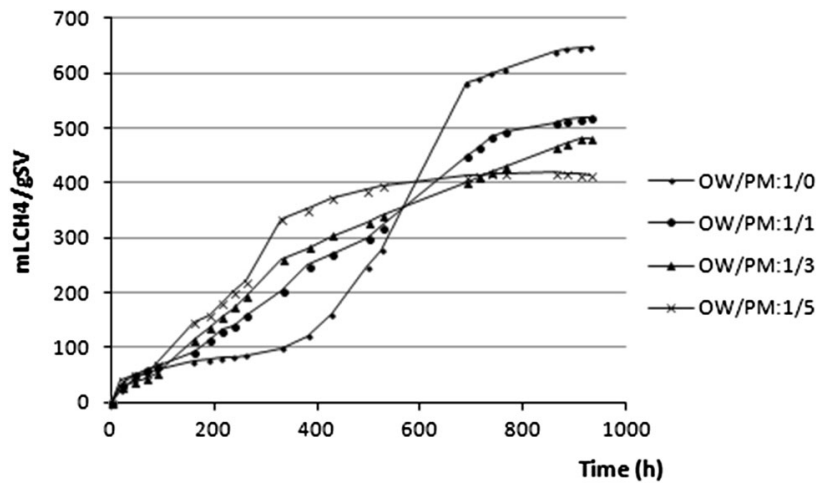

Fig. 2 Cumulative specific methane production curves of the waste mixtures at different OW/PM ratios

Table 3 Waste elemental composition

\begin{tabular}{|c|c|c|c|c|c|c|c|c|}
\hline \multirow[t]{2}{*}{ Waste } & \multicolumn{7}{|c|}{ Elemental composition $^{\mathrm{a}}$} & \multirow{2}{*}{$\begin{array}{l}\text { Theoretical methane potential } \\
B_{0, \mathrm{Th}}\left(\mathrm{mLCH}_{4} \cdot \mathrm{gVS}^{-1}\right)\end{array}$} \\
\hline & $\% \mathrm{C}$ & $\% \mathrm{H}$ & $\% \mathrm{~N}$ & $\% \mathrm{P}$ & $\% \mathrm{~S}$ & $\%$ Ash & $\% \mathrm{O}^{\mathrm{b}}$ & \\
\hline OW & 64.13 & 9.6 & 1.2 & 0.2 & 0.1 & 4.2 & 20.6 & 824 \\
\hline PM & 34.5 & 4.7 & 2.8 & 0.4 & 0.7 & 31.6 & 25.3 & 516 \\
\hline Mixture 1/1 & 50.3 & 7.1 & 1.8 & 0.3 & 0.4 & 18.1 & 22.0 & 670 \\
\hline Mixture $1 / 3$ & 42.09 & 5.8 & 2.3 & 0.4 & 0.6 & 24.8 & 24.1 & 603 \\
\hline Mixture $1 / 5$ & 40.4 & 5.7 & 2.5 & 0.4 & 0.6 & 26.0 & 24.4 & 577 \\
\hline
\end{tabular}

\footnotetext{
a $\%$ dry-matter weight basis

b \%O estimated

${ }^{c}$ Calculated assuming a $\mathrm{C}_{\mathrm{a}} \mathrm{H}_{\mathrm{n}} \mathrm{O}_{\mathrm{b}} \mathrm{N}_{\mathrm{c}}$ composition ( $S$ and $P$ neglected)
} 
as substrate (in $\mathrm{mLCH}_{4} \mathrm{~L}^{-1} \mathrm{~h}^{-1}$ : 3.3, 3.4 and 5.9 for OW/ PM rates of $1 / 1,1 / 3$ and $1 / 5$, respectively) but a stronger inhibition was observed for the test where only OW was added as substrate. In this case, the lag phase extended to $400 \mathrm{~h}$, but the process recovered. This phenomenon agrees with Pereira et al. (2005) that demonstrated that inhibition by LCFA accumulation was a reversible phenomenon more likely to be related to physical transport limitations, than to metabolic functions.

As expected, mixtures with higher percentage of OW showed higher specific methane potentials. This trend is in accordance with the results of the $B_{0, T h}$ calculated by the Buswell's equation (Table 3), however experimental values are considerably lower than the theoretical ones (in $\mathrm{mLCH}_{4} \mathrm{gVS}^{-1}: 648,520,480$ and 415 for OW/PM rates of $1 / 0,1 / 1,1 / 3$ and $1 / 5$, respectively). This could mean that the maximum theoretical conversion has not been reached during the experimentation (that is something usual), but also that with Buswell's equation neither the use of substrate nor other routes of conversion of organic matter are taken into consideration for the production of bacterial biomass (de Lemos 2007).

Part of the biodegradable organic matter, used by the bacteria to grow, does not contribute to the BMP value. In other words, the Buswell's equation does not account for substrate biodegradability, neglecting cellular synthesis, when in reality, part of the biodegradable organic matter is used by the bacteria to grow, and does not contribute to biogas generation. In fact, Buswell reported that during the digestion of pure carbohydrates, an average of $12 \%$ of the total carbon-fed was lost in the cell protoplasm which was not accounted for by their formula. The Buswell's equation therefore overestimates the BMP value. Furthermore, it is known that in the presence of specific inorganic donors (such as nitrate, sulphate or sulphite) and some by-products of the cellular metabolism (Zhou et al. 2013) the production of methane can decrease.

Taking in mind the operation of a two-phase anaerobic pilot plant, the optimal scenario assayed corresponds to the ratio OW/PM:1/5 v/v where shorter lag periods will make it possible to operate at lower HRT.

During the first days of the assay, methane content in biogas was low, but it increased until reaching percentages of $70.6,69.2,69.1$ and 69.5 for OW/PM rates of $1 / 0,1 / 1,1 / 3$ and $1 / 5$, respectively. A fact that is observed in all the mixtures is that the lower the OW/PM ratio is in the batch assay, the faster the methane content increases in the biogas. The breakdown of the complex substrate takes place during those first stages, with its consequent acid-components generation and buffer consumption $\left(\mathrm{NaHCO}_{3}\right)$, changing the $\mathrm{HCO}_{3}{ }^{-}$/ $\mathrm{CO}_{2}$ balance and releasing $\mathrm{CO}_{2}$ from the liquid to the gas phase. Therefore, a substrate more easily degradable will
Table 4 Experimental HRT

\begin{tabular}{llll}
\hline & $\begin{array}{l}\text { HRT acidogenic } \\
\text { reactor (day) }\end{array}$ & $\begin{array}{l}\text { HRT methanogenic } \\
\text { reactor (day) }\end{array}$ & $\begin{array}{l}\text { Total HRT } \\
\text { (day) }\end{array}$ \\
\hline Run 1 & 4 & 20 & 24 \\
Run 2 & 2 & 18 & 20 \\
Run 3 & 1 & 15 & 16 \\
Run 4 & 0.5 & 11.5 & 12 \\
\hline
\end{tabular}

produce more $\mathrm{CO}_{2}$ and in consequence a biogas with lower methane content at the beginning of the assay.

Two-phase reactor behaviour

The sludge used as inoculum in the reactors was the same used in the biodegradability test. Before loading the reactors, the sludge was clearly washed.

The AR was fed with the waste mixture of oily waste and $\mathrm{PM}$ (after previous grinding) at an optimum mixing ratio of $1 / 5(\mathrm{OW} / \mathrm{PM})$, and $\mathrm{pH}$ was controlled within the range 5.5-7.0 by the addition of $\mathrm{H}_{2} \mathrm{SO}_{4}$. The mixture was then pumped into the methane fermentation reactor. No chemicals addition for $\mathrm{pH}$ control was required in this stage. After stabilizing the reactor, studies were conducted under the steady state conditions. At the steady state of the bioreactors, performance parameters like COD, $\mathrm{pH}$ and solids removal were relatively constant [standard deviation (SD) $<15 \%$ ].

In order to find the optimum operating conditions for SCOD and TDS removal, an experiment consisting of four runs with successively decreasing HRT in acidogenic and methanogenic reactors, and thus, total HRT, was performed. The system was operated at the HRT showed in Table 4. The $\mathrm{pH}$, temperature and biogas production of acidogenic and methanogenic reactors were monitored online using a programmable logic control.

\section{sCOD removal}

The results obtained during the process run of different HRTs are plotted in Fig. 3a. The average sCOD concentration for feed varies from 17,500 to $19,600 \mathrm{mg} \mathrm{L}^{-1}$ (min: 14,982 $\mathrm{mg} \mathrm{L}^{-1}$; max: $23,300 \mathrm{mg} \mathrm{L}^{-1}$; $\mathrm{SD}: 13.8 \%$ ), for AR outlet varies from 10,520 to $13,500 \mathrm{mg} \mathrm{L}^{-1}$ (min: $8,928 \mathrm{mg} \mathrm{L}^{-1}$; $\max : 18,150 \mathrm{mg} \mathrm{L}^{-1}$; SD: $7.1 \%$ ) and for MR varies from 2,550 to 3,500 mg L ${ }^{-1}$ (min: $890 \mathrm{mg} \mathrm{L}^{-1}$; max: $3,895 \mathrm{mg} \mathrm{L}^{-1}$; SD: $4.2 \%$ ). From Fig. $3 \mathrm{~b}$, it is evident that sCOD removal efficiency was in the range of $31.1-44.0 \%$ in the AR and $71.3-75.9 \%$ in the MR at various HRT. The maximum SCOD removal efficiency of $75.9 \%$ at 24 days of HRT was achieved in the MR, and $44.0 \%$ at 20 days of HRT was achieved in the acidogenic 

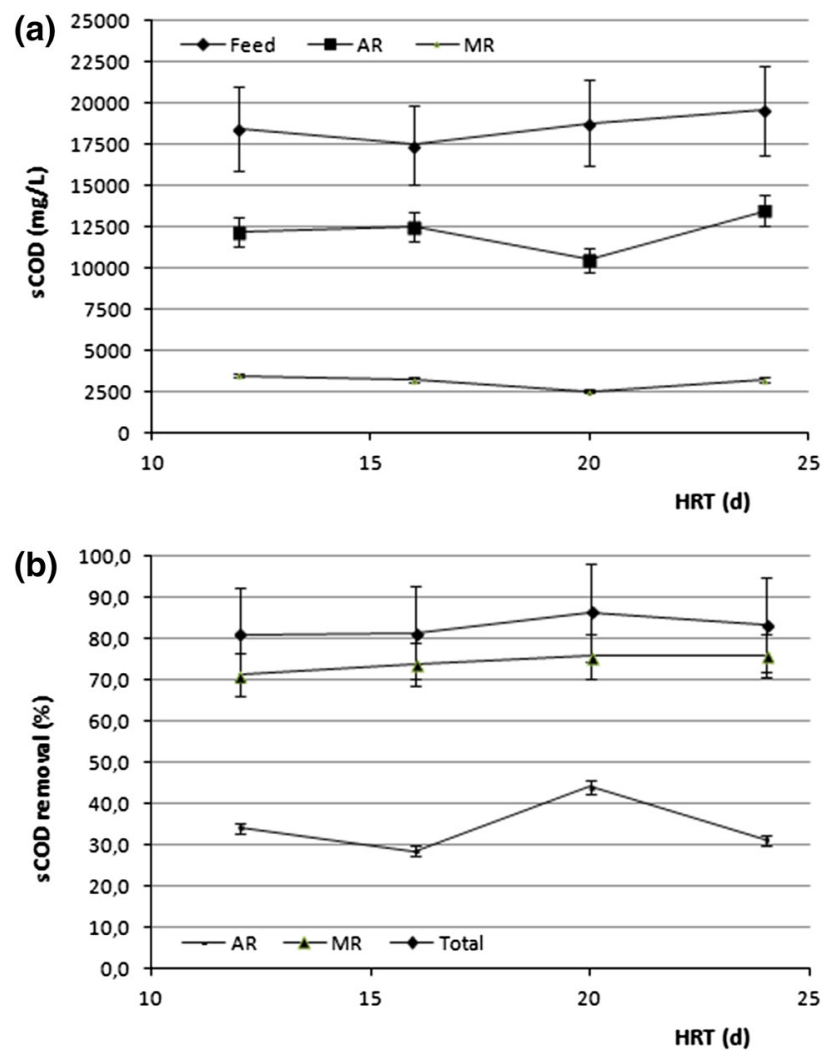

Fig. 3 sCOD at different HRTs a sCOD concentration; b sCOD removal

phase. The maximum total sCOD removal efficiency of $86.4 \%$ was also achieved at 20 days of HRT. The lower efficiency of the acidogenic phase is due to the complex state of the mixture, even after grinding, while in the methanogenic phase the substrate enters as simple shortchain compounds after hydrolysis and the fermentation process in the AR.

\section{TDS removal}

The average TDS concentration for feed varies from 10,400 to $11,800 \mathrm{mg} \mathrm{L}^{-1}$ (min: $7,652 \mathrm{mg} \mathrm{L}^{-1}$; $\max$ : $13,528 \mathrm{mg} \mathrm{L}^{-1}$; SD: $10.7 \%$ ), for AR outlet varies from 9,150 to $10,200 \mathrm{mg} \mathrm{L}^{-1}$ (min: $7,925 \mathrm{mg} \mathrm{L}^{-1}$; $\max$ : $12,925 \mathrm{mg} \mathrm{L}^{-1}$; SD: $8.3 \%$ ) and for MR varies from 2,040 to $2,800 \mathrm{mg} \mathrm{L}^{-1}$ (min: $1,552 \mathrm{mg} \mathrm{L}^{-1}$; max: 3,963 $\mathrm{mg} \mathrm{L}^{-1}$; SD: $7.8 \%)$.

Figure 4 shows the TDS removal efficiency of acidogenic and methanogenic reactors at various HRT.

It is clear that the TDS removal efficiency in the AR is in the order of 8.2-18.9\% for various HRT, and in MR, TDS removal efficiency varies from 69.9 to $77.7 \%$. The maximum total TDS removal efficiency of $81.9 \%$ was achieved at 20 days of HRT.

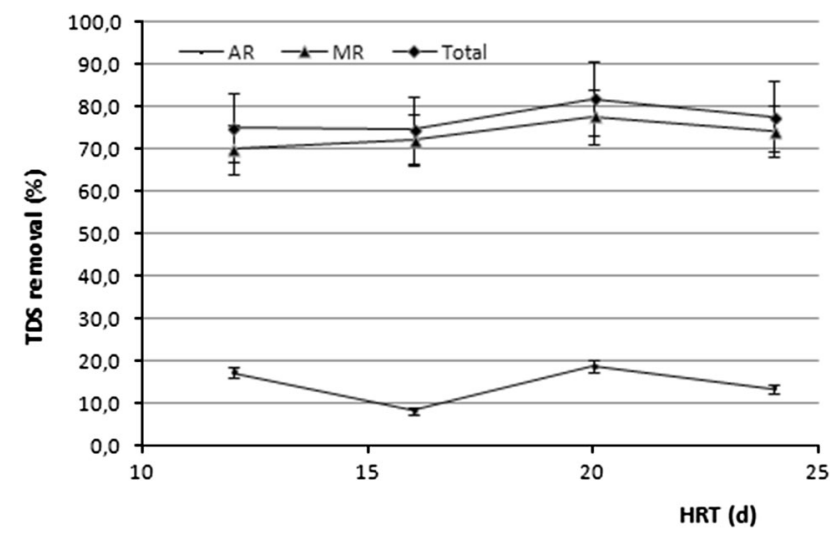

Fig. 4 TDS removal at different HRTs

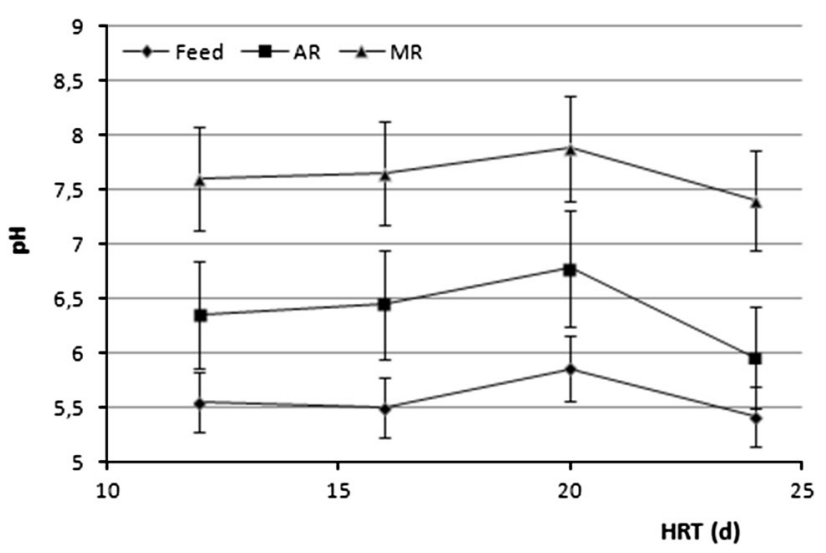

Fig. $5 \mathrm{pH}$ at different HRTs

\section{$p H$, alkalinity and LCFA concentration}

$\mathrm{pH}$ changes in the effluent of the reactors at various HRT are shown in Fig. 5. It is clear that the average $\mathrm{pH}$ of the raw feed (after acidification with $\mathrm{H}_{2} \mathrm{SO}_{4}$ ), AR outlet and MR outlet are in the range of 5.42-5.86 (min: $5.18 \mathrm{mg} \mathrm{L}^{-1}$; $\max : \quad 6.31 \mathrm{mg} \mathrm{L}^{-1} ; \quad \mathrm{SD}: \quad 6.2 \%$ ), 5.96-6.78 (min: $5.50 \mathrm{mg} \mathrm{L}^{-1}$; $\max : 7.00 \mathrm{mg} \mathrm{L}^{-1} ; \mathrm{SD}: 7.8 \%$ ) and 7.41-7.88 (min: $7.20 \mathrm{mg} \mathrm{L}^{-1}$; $\max : 8,55 \mathrm{mg} \mathrm{L}^{-1}$; SD: $4.9 \%$ ), respectively. The alkalinity values for AR vary from 320 to $360 \mathrm{mg} \mathrm{L}^{-1}$ (min: $286 \mathrm{mg} \mathrm{L}^{-1}$; $\max : 496 \mathrm{mg} \mathrm{L}^{-1}$; SD: $8.0 \%$ ), whereas for the MR the alkalinity values vary from 520 to $550 \mathrm{mg} \mathrm{L}^{-1}$ (min: $420 \mathrm{mg} \mathrm{L}^{-1}$; max: $766 \mathrm{mg} \mathrm{L}^{-1}$; SD: $5.3 \%$ ). In this study, $\mathrm{pH}$ and alkalinity values were under control for the stable operation of the MR.

Accumulation of oleate and linoleate was observed during the first days of operation for all the assays. Then, a decrease in these acids concentration, which correlated with the accumulation that occurred for palmitate was observed, in accordance with Cirne et al. (2007). The concentrations of the other LCFA were always much lower. 


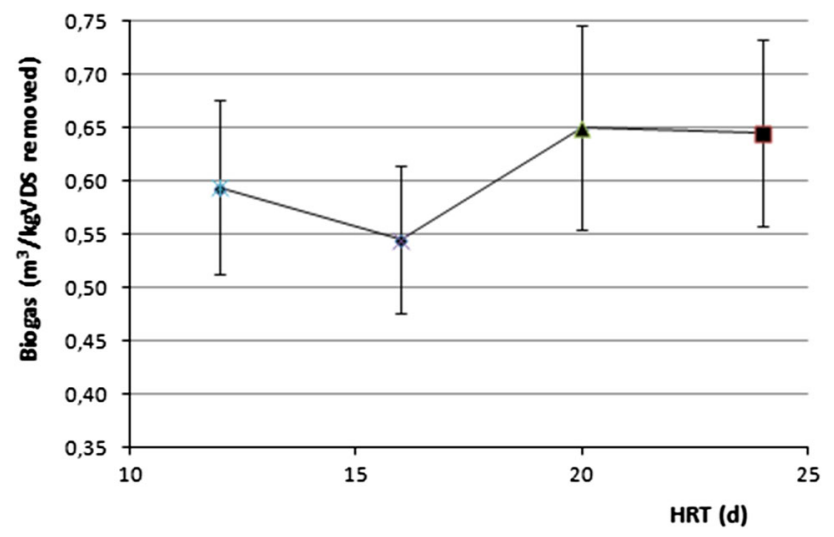

Fig. 6 Biogas production at different HRTs

Angelidaki et al. (2002) reported inhibition for oleate concentrations higher than $200 \mathrm{mg} \mathrm{L}^{-1}$. Furthermore, Salminen et al. (2000) found that palmitate concentrations were inhibitory during the degradation of solid poultry slaughterhouse waste. However, this does not seem to have been the case in the present study. No inhibition of methanogenic bacteria activity has been observed during the experimentation, even working with $\mathrm{pH}$ values in the MR inlet lower than 6.

Beccari et al. (1998) applied a two-reactor system with partial phase separation for treating olive oil effluents and reported that in the conversion between oleic acid and palmitic acid, the saturation from oleic to stearic was the limiting step, whereas the first step of $\beta$-oxidation (stearic to palmitic) proceeded quickly.

\section{Biogas}

Biogas production at different HRTs for the whole system is shown in Fig. 6. The average methane content in the biogas ranged between 63 and $65 \%$ during the experiments. The average maximum biogas production of $0.65 \mathrm{~m}^{3} \mathrm{kgVDS}^{-1}$ removed (min: $0.622 \mathrm{~m}^{3} \mathrm{kgVDS}^{-1}$; max: $0.664 \mathrm{~m}^{3} \mathrm{kgVDS}^{-1}$; SD: $\left.14.8 \%\right),\left(65 \% \mathrm{CH}_{4}\right)$ was achieved at 20 days of HRT, whereas $0.645 \mathrm{~m}^{3} \mathrm{kgVDS}^{-1}$ removed (min: $0.600 \mathrm{~m}^{3} \mathrm{kgVDS}^{-1}$; $\max : 0.654 \mathrm{~m}^{3}$ $\mathrm{kgVDS}^{-1}$; SD: $13.6 \%$ ) for 24 days of HRT, $0.594 \mathrm{~m}^{3} \mathrm{kgVDS}^{-1}$ removed (min: $0.585 \mathrm{~m}^{3} \mathrm{kgVDS}^{-1}$; max: $0.621 \mathrm{~m}^{3} \mathrm{kgVDS}^{-1}$; SD: $13.8 \%$ ) for 12 days of HRT and $0.545 \mathrm{~m}^{3} \mathrm{kgVDS}^{-1}$ removed (min: $0.538 \mathrm{~m}^{3} \mathrm{kgVDS}^{-1}$; $\max$ : $0.605 \mathrm{~m}^{3} \mathrm{kgVDS}^{-1}$; $\mathrm{SD}$ : $12.8 \%$ ) for 16 days of HRT. Biogas production is directly related to SCOD stabilization, for example without biogas production minimal SCOD and VDS removal occurs (Grady et al. 1999).
It can be observed that, also here, experimental values are lower than the theoretical ones obtained by applying Buswell's equation (Table 3 ).

According to Shen et al. (2013), the statistical coefficients of variation (SD) for biogas production can directly reflect the buffering capability of digestion system to newfed substrates and the stability of digestion performance. The statistical calculation results indicated that the SD for methane production in the stable periods of the two-phase system was always lower than $15 \%$. Thus, it could be deduced that the $\mathrm{AD}$ was stable under the whole experimentation.

This study shows that oily wastes can be treated successfully without high dilution and without adding chemical substances (apart from sulphuric acid for $\mathrm{pH}$ control) if they are co-digested with substrates containing high level of ammonium nitrogen and alkalinity to compensate for their lack in these wastes.

The same conclusion was previously stated by other authors (Angelidaki and Ahing 1997; Angelidaki et al. 2002; Fezzani and Cheikh 2007).

\section{Conclusion}

A pilot scale two-phase semi-continuous stirred tank reactor was used to treat oily waste with PM as co-substrate (1/5 v/v) at different HRTs (12, 16, 20, and 24 days). The experimental results indicated that the most suitable HRT for an efficient run of the reactor was 20 days. The maximum removal of SCOD and TDS achieved in the system was 86.4 and $81.9 \%$, respectively. The biogas production reached a maximum of $0.65 \mathrm{~m}^{3} \mathrm{kgVDS}^{-1}$ removed $(65 \%$ $\mathrm{CH}_{4}$ ) at 20 days HRT. The $\mathrm{pH}$ and alkalinity of the reactors effluent were stable under 20 days of HRT.

From the results obtained, it was clear that two-phase AD system has given good performances concerning methane productivity, sCOD and TDS removal efficiencies and effluent quality compared with those given by conventional one-phase AD reactors.

Therefore, two-phase AD could be a very feasible alternative, eco-friendly and sustainable treatment system for the waste generated by used vegetable oil processing companies and pig farms.

Furthermore, co-digestion of OW and PM on a twophase anaerobic system is a promising method for the recovery of bioenergy.

Acknowledgments The authors gratefully acknowledge support of this work by the LIFE + Program under the responsibility of the Directorate General for the Environment of the European Commission through the agreement LIFE $09 \mathrm{ENV/E} / 000451-\mathrm{VALUVOIL}$ project. 


\section{References}

Ahrin BK (2003) Perspectives for anaerobic digestion. In: Ahring BK (ed) Biomethanation I. Advances in biochemical engineering/ biotechnology. Sringer, Berlin, pp 1-30

American Public Health Association (APHA) (2005) Standard methods for the examination of water and wastewater, 21th edn. APHA, Washington, DC

Angelidaki I, Ahing BK (1997) Co-digestion of olive mill wastewaters with manure, household waste or sewage sludge. Biodegradation 8:221-226

Angelidaki I, Ahing BK, Deng H, Schmidt JE (2002) Anaerobic digestion of olive mill effluents together with swine manure in USAB reactors. Water Sci Technol 45(10):213-218

Appels L, Lauwers J, Degrève J, Helsen L, Lievens B, Willems K, Van Impe J, Dewil R (2011) Anaerobic digestion in global bioenergy production: potential and research challenges. Renew Sust Energy Rev 15(9):4295-4301

Beccari M, Majone M, Torrisi L (1998) Two-reactor system with partial phase separation for anaerobic treatment of olive oil mill effluents. Water Sci Technol 38(4-5):53-60

Borja R, Banks CJ (1995) Anaerobic digestion of ice-cream wastewater: a comparison of single and two phase reactor systems. Bull Environ Contam Toxicol 54(3):466-471

Borja R, Rincón B, Raposo F, Alba J, Martin A (2002) A study of anaerobic digestibility of two-phase olive mill solid waste (OMSW) at mesophilic temperature. Process Biochem 38:733-742

Bouallagui H, Touhami Y, Cheikh RB, Hamdi M (2005) Bioreactor performance in anaerobic digestion of fruit and vegetable. Process Biochem 40:989-995

Chhetri AB, Tango MS, Budge SM, Islam MR (2008) Non-edible plant oils as new sources for biodiesel production. Int J Mol Sci 9:169-180

Cirne D, Paloumet X, Björnsson L, Alves M, Mattiassona B (2007) Anaerobic digestion of lipid-rich waste-effects of lipid concentration. Renew Energy 32:965-975

de Lemos (2007) Anaerobic reactors: biological wastewater treatment, vol 4. IWA Publishing, London

Demirel B, Yenigün O (2002) Two-phase anaerobic digestion processes: a review. J Chem Technol Biotechnol 77(7):743-755

Demirer GN, Chen S (2005) Two-phase anaerobic digestion of unscreened dairy manure. Process Biochem 40:3542-3549

EU (2006) Biofuels in the European Union-A vision for 2030 and beyond. Report of the biofuel research advisory council

Fezzani B, Cheikh RB (2007) Anaerobic co-digestion of olive mill wastewater with olive mill solid waste in a tubular digester at a mesophilic temperature. Bioresour Technol 98:769-774

Göblös S, Portörő P, Bordás D, Kálmán M, Kiss I (2008) Comparison of the effectivities of two-phase and single-phase anaerobic sequencing batch reactors during dairy wastewater treatment. Renew Energy 33(5):960-965

Grady C, Daigger G, Lim H (1999) Biological wastewater treatment, 2nd edn. Marcel Dekker, New York

Guerrero L, Omil F, Mendez R, Lema JM (1999) Anaerobic hydrolysis and acidogenesis of wastewaters from food industries with high content of organic solids and protein. Water Res 33(15):3281-3290

Hidalgo D, Sastre E, Gómez M, Nieto P (2013) Evaluation of pretreatment processes for increasing biodegradability of agro-food wastes. Environ Technol 33(13):1497-1503

Hong V (2011) Anaerobic digestion of oil-rich solid waste. J Biotechnol 9(1):45-53

Ince O (1998) Performance of a two-phase anaerobic digestion system when treating dairy wastewater. Water Res 32(9):2707-2713
Kulkarni MG, Dalai AK (2006) Waste cooking oil—an economical source for biodiesel: a review. Ind Eng Chem Res 45:2901-2913

Lalman JA, Bagley DM (2001) Anaerobic degradation and methanogenic inhibitory effects of oleic stearic acids. Water Res 35(12):2975-2983

Lesteur M, Bellon-Maurel V, Gonzalez C, Latrille E, Roger JM, Junqua G, Steyer JP (2010) Alternative methods for determining anaerobic biodegradability: a review. Process Biochem 45:431-440

Li R, Chen S, Li X (2010) Biogas production from anaerobic codigestion of food waste with dairy manure in a two-phase digestion system. Appl Biochem Biotechnol 160(2):643-654

Mobarak-Qamsari E, Kasra-Kermanshahi R, Nosrati M, Amani T (2012) Enzymatic pre-hydrolysis of high fat content dairy wastewater as a pretreatment for anaerobic digestion. Int $\mathrm{J}$ Environ Res 6(2):475-480

Neves L, Pereira M, Mota M, Alves M (2009) Detection and quantification of long chain fatty acids in liquid and solid samples and its relevance to understand anaerobic digestion of lipids. Bioresour Technol 100(1):91-96

Palenzuela A (1999) Anaerobic digestion of fish processing wastewater with special emphasis on hydrolysis of suspended solids. A.A. Balkema, The Netherlands

Pastor L, Ruiz L, Pascual A, Ruiz B (2013) Co-digestion of used oils and urban landfill leachates with sewage sludge and the effect on the biogas production. Appl Energy 107:438-445

Pereira MA, Pires OC, Mota M, Alves MM (2005) Anaerobic biodegradation of oleic and palmitic acids: evidence of mass transfer limitations caused by long chain fatty acid accumulation onto the anaerobic sludge. Biotech Bioeng 92(1):15-23

Refaat A (2010) Different techniques for the production of biodiesel from waste vegetable oil. Int J Environ Sci Tech 7(1):183-213

Salminen E, Rintala J, Lokshina LYA, Vavilin VA (2000) Anaerobic batch degradation of solid poultry slaughterhouse waste. Water Sci Technol 41:33-41

SenthilKumar M, Gnanapragasam G, Arutchelvan V, Nagarajan S (2011) Influence of hydraulic retention time in a two-phase upflow anaerobic sludge blanket reactor treating textile dyeing effluent using sago effluent as the co-substrate. Environ Sci Pollut Res 18:649-654

Shen F, Yuan H, Pang Y, Chen S, Zhu B, Zou D, Liu Y, Mac J, Yu L, Li X (2013) Performances of anaerobic co-digestion of fruit \& vegetable waste (FVW) and food waste (FW): single-phase vs. two-phase. Bioresour Technol 144:80-85

Solera R, Romero LI, Sales D (2002) The evolution of biomass in a two-phase anaerobic treatment process during start-up. Chem Biochem Eng Q 16(1):25-29

Torrijos M, Thalla AK, Sousbie P, Bosque F, Delgene's JP (2008) Anaerobic digestion of residues from production and refining of vegetable oils as an alternative to conventional solutions. Water Sci Technol 58(9):1871-1878

Travieso L, Dominguez JR, Rincón B, Sánchez E, Benítez F, Borja R, Raposo F, Colmenarejo MF (2008) Batch culture growth of chlorella zofingiensis on effluent derived from two-stage anaerobic digestion of two-phase olive mill solid waste. Electron $\mathrm{J}$ Biotechnol 11(2):1-8

Wang Z, Banks CJ (2003) Evaluation of a two-stage anaerobic digester for the treatment of mixed abattoir wastes. Process Biochem 38(9):1267-1273

Wust E (2003) Single-phase and two-phase cheese wastewater treatment by anaerobic SBRs. PhD thesis, Civil, Construction and Environmental Engineering Department, Marquette University, Milwaukee, Wisconsin

Yang YQ, Shen DS, Li N, Xu D, Long YY, Lu XY (2013) Codigestion of kitchen waste and fruit-vegetable waste by two- 
phase anaerobic digestion. Environ Sci Pollut Res Int 20(4):2162-2167

Yu HW, Samani Z, Hanson A, Smith G (2002) Energy recovery from grass using two-phase anaerobic digestion. Waste Manag 22:1-5

Zhang B, Cai W, He P (2007) Influence of lactic acid on the twophase anaerobic digestion of kitchen wastes. J Environ Sci 19:244-249

Zhang P, Chen Y, Zhou Q (2010) Effect of surfactant on hydrolysis products accumulation and short-chain fatty acids (SCFA) production during mesophilic and thermophilic fermentation of waste activated sludge: kinetic studies. Bioresour Technol 101(18):6902-6909

Zhang L, Lee YW, Jahng D (2011) Anaerobic co-digestion of food waste and piggery wastewater: focusing on the role of trace elements. Bioresour Technol 102(8):5048-5059

Zhou X, Meile L, Kreuzer M, Zeitz J (2013) The effect of saturated fatty acids on methanogenesis and cell viability of Methanobrevibacter ruminantium. Archaea. doi:10.1155/2013/106916 